\title{
Corrigendum: Regulation of multiple carbon monoxide consumption pathways in anaerobic bacteria
}

\author{
Stephen M. Techtmann ${ }^{1}$, Albert S. Colman ${ }^{2}$, Michael B. Murphy ${ }^{3}$, Wendy S. Schackwitz ${ }^{4}$, \\ Lynne A. Goodwin ${ }^{5}$ and Frank T. Robb ${ }^{1 *}$ \\ ${ }^{1}$ Institute of Marine and Environmental Technology, University of Maryland, Baltimore, MD, United States, ${ }^{2}$ Department of the \\ Geophysical Sciences, University of Chicago, Chicago, IL, United States, ${ }^{3}$ GE Healthcare, Piscataway, NJ, United States, \\ ${ }^{4}$ Department of Energy, Joint Genome Institute, Walnut Creek, CA, United States, ${ }^{5}$ Bioinformatics, Joint Genome Institute, \\ Los Alamos National Laboratory, Los Alamos, NM, United States
}

Keywords: carbon monoxide, thermophiles, hydrogenogens, carboxydotrophs, Carboxydothermus hydrogenoformans, carbon monoxide dehydrogenase, CooA

\section{A corrigendum on}

Regulation of multiple carbon monoxide consumption pathways in anaerobic bacteria by Techtmann, S. M., Colman, A. S., Murphy, M. B., Schackwitz, W. S., Goodwin, L. A., and Robb, F. T. (2011). Front. Microbio. 2:147. doi: 10.3389/fmicb.2011.00147

\section{OPEN ACCESS}

Edited and reviewed by: Ludmila Chistoserdova, University of Washington, United States

*Correspondence: Frank T. Robb

frobb@som.umaryland.edu

Specialty section:

This article was submitted to Evolutionary and Genomic Microbiology,

a section of the journal Frontiers in Microbiology

Received: 17 April 2018 Accepted: 30 April 2018

Published: 05 July 2018

Citation:

Techtmann SM, Colman AS, Murphy MB, Schackwitz WS, Goodwin LA and Robb FT (2018)

Corrigendum: Regulation of multiple carbon monoxide consumption pathways in anaerobic bacteria.

Front. Microbiol. 9:1016. doi: 10.3389/fmicb.2018.01016
In the original article, there was a mistake in Figure 2 as published. Specifically, panel 2D was included in error thus, the authors wish to remove it. Consequently, the caption for Figure 2 has been updated due to the removal of 2D, and the in-text citation has been removed from the following sentence: "E. coli overexpressing wild type CooA-2 acquired a red color similar to the color of CooA-1 expressing E. coli as described in Youn et al. (2004) due to the accumulation of the heme containing protein (Figure 2D)" in Results section, subsection "Expression and Characterization of CooA-2". The corrected Figure 2 appears below.

Additionally, there was a mistake in Figure 4. In the figure, the gel images had been edited. The no-protein control lane was moved to be adjacent to the relevant experimental lanes by removing empty lanes or ones with other controls. The authors neglected to mention this adjustment in the submission of the paper and wish to replace Figure 4 with an updated version where the spliced lanes have been clearly separated from the contiguous gel regions with black lines and white space to indicate where the control lanes are. The corrected Figure 4, as well as the original gel image used to prepare Figure 4, appear below.

The authors apologize for these oversights and state that these errors do not change the scientific conclusions of the article in any way.

The original article has been updated.

Conflict of Interest Statement: The authors declare that the research was conducted in the absence of any commercial or financial relationships that could be construed as a potential conflict of interest.

Copyright $\odot 2018$ Techtmann, Colman, Murphy, Schackwitz, Goodwin and Robb. This is an open-access article distributed under the terms of the Creative Commons Attribution License (CC BY). The use, distribution or reproduction in other forums is permitted, provided the original author(s) and the copyright owner(s) are credited and that the original publication in this journal is cited, in accordance with accepted academic practice. No use, distribution or reproduction is permitted which does not comply with these terms. 

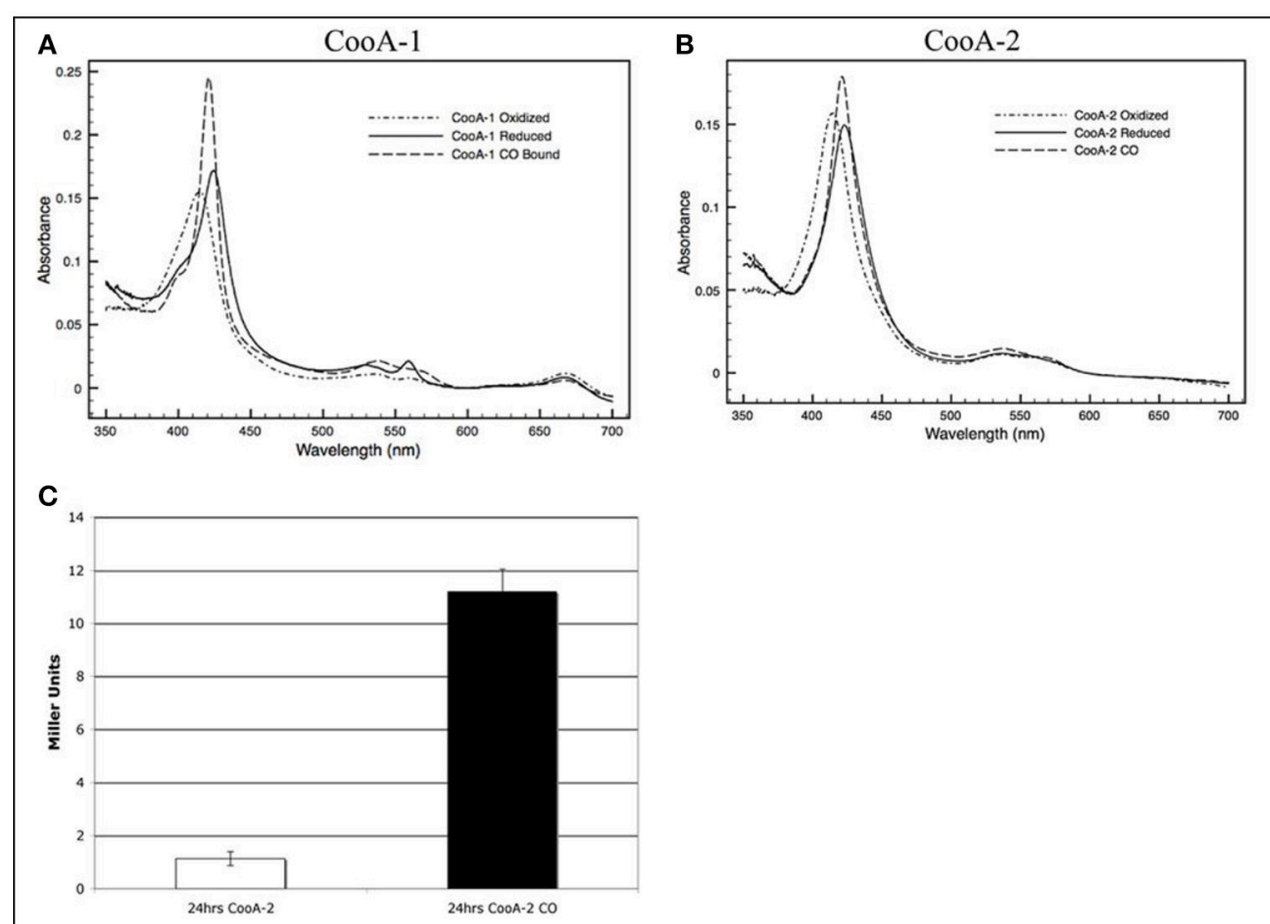

FIGURE 2 | Visible spectra of a $2.2 \mu \mathrm{M}$ (A) CooA-1 and (B) CooA-2. Dotted lines indicate the spectrum of oxidized CooA. Solid line indicates reduced CooA. Dashed line indicates reduced CooA under $1 \mathrm{~atm}$ of $\mathrm{CO}$. (C) $\beta$-galactosidase activity of CooA-2 expressing $E$. coli DH5 $\alpha$ with a lacZ under the control of the $R$. rubrum cooF promoter. Experiments with $\mathrm{CO}$ were grown with $2 \% \mathrm{CO}$ in the headspace of the culture.

\section{A} CooA-1 ACS

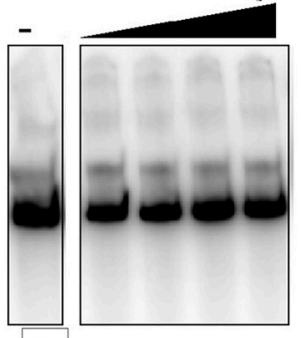

C CooA-2 ACS

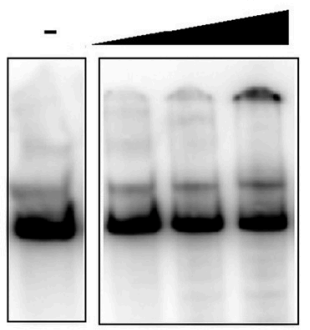

B

\section{CooA-1 cooC}

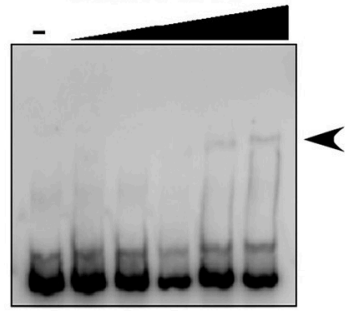

D

CooA-2 $\operatorname{coo} C$

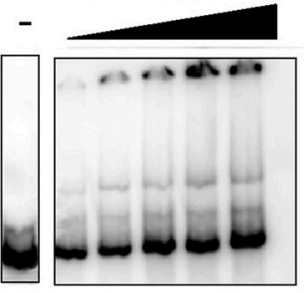

FIGURE 4 | Electrophoretic mobility shift assays at $25^{\circ} \mathrm{C}$. Gel shift results showing the binding of COOA-1 or CooA-2 to either pacs or the pcooChyd promters from $C$. hydrogenoformans. Arrows indicate formation of the

CooA-promoter complex. (A) CooA-1 binding to pacs (Protein added: 3, 6, 12, $18 \mu \mathrm{g} / \mathrm{ml}$ ). (B) CooA-1 binding to pcooC hyd (Protein added: 3, 6, 9, 12, 15 $\mu \mathrm{g} / \mathrm{mll}$ ). (C) CooA-2 binding to pacs (Protein added: 3, 6, $9 \mu \mathrm{g} / \mathrm{ml}$ ). (D) CooA-2 binding to pcoochyd (Protein added: 3, 6, 9, 12, $15 \mu \mathrm{g} / \mathrm{ml}$ ).

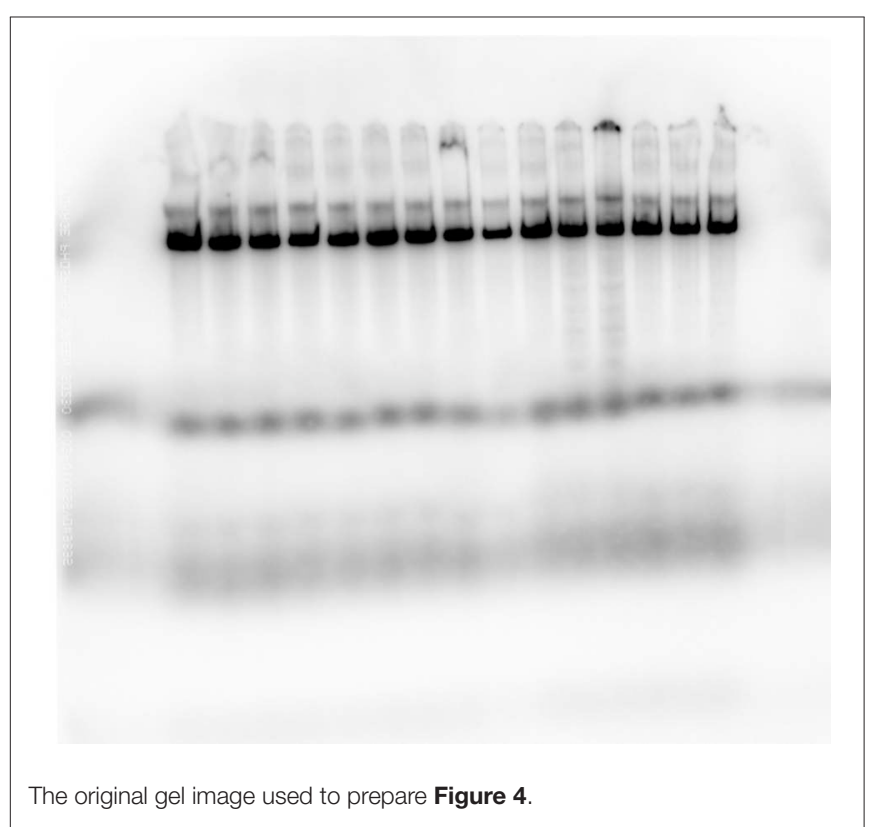

